\title{
Embracing Technology in Auditing Courses: Opportunities, Methodology and Challenges
}

\author{
Nurmazilah Mahzan¹, Rusnah Muhamad, \\ Yazkhiruni Yahya, Suhaily Shahimi
}

\begin{abstract}
The usage of technology in auditing has evolved since the 1950s and the density is growing exponentially. Auditing technology refers to any tool that can enhance the auditor's capacity to perform an audit task. The most prominent type of audit technology being used is generalized audit (GAS) under the category of computer-assisted audit tools and techniques (CAATTs). Consistent with the proliferation of GAS usage in auditing, graduates are expected to possess sufficient knowledge and skills pertaining to these tools in order to meet the demand by the auditing profession. However, many universities outside America that offer auditing subjects have yet to integrate audit technology into the teaching of these courses. Consequently, the graduates' awareness and skills in using the audit technology is very limited. This study has twofold objectives. First, it explores the opportunities, methodologies and challenges in incorporating GAS into the teaching of auditing courses to accounting undergraduates through review of extant literature. Second it analyses the effect of the teaching methodology that we choose on the students' learning process. Data on the students' responses are collected using survey questionnaires as well as students' test performance. Our preliminary findings reveal that students responded positively towards the opportunity and benefits of GAS in the auditing process. We employed hands-on practical usage of the software during tutorial classes as a methodology to impart GAS usage skills. Among the challenges encountered were the assessment method, software availability and licensing.
\end{abstract}

Keywords: CAATTs, Teaching Technology, Auditing

\section{Introduction and Motivations}

Computer Assisted Audit Techniques and Tools (CAATTs) have become an essential tool for auditors, particularly when auditing businesses that heavily

\footnotetext{
1 Corresponding author: Dr Nurmazilah Mahzan is a Senior Lecturer at the Faculty of Business \& Accountancy, University of Malaya, email: nurmazilah@um.edu.my. Datin Dr Rusnah Muhamad is an Associate Professor at the Faculty of Business \& Accountancy, University of Malaya. Yazkhiruni Yahya and Suhaily Shahimi are SLAI Fellow at the Faculty of Business \& Accountancy, University of Malaya.
} 
rely on technology based processing. (CICA, 1994; Pogrob \& Isenberg, 1999; Paukowits, 2000; Hudson, 1998). CAATTs are computer tools and techniques that an auditor (external or internal) uses as part of their audit procedures to collect and process data significant to the audit engagement. (Singleton, 2003). Recent literature (for example, Grand 2001) has shown that the types of CAATT mostly used by auditors are classified as including the following groups: electronic working papers, fraud detection, generalized audit software (GAS) for information retrieval and analysis, network security, continuous monitoring, audit reporting, database of audit history, computer based training, electronic commerce and Internet security.

More importantly, these developments and the rapid growth of computerization of most economic transactions, described as Real Time Economy, caused the roles and approaches of auditing practices to converge (Vasarhelyi, Teeter and Krahel, 2010). These changes have contributed to the new level of expectations concerning the skill and quality of auditors from employers who now demand that the accounting and auditing professionals are equipped with skills in information systems (Vasarhelyi, Teeter and Krahel, 2010). The release of Albrecht and Sack's (2000) monograph emphasizes the need for improved technology education, which, ultimately, will develop students' ability to learn, such skills.

There are three major developments in auditing techniques in this period (Porter et al., 2005, p. 19), which include:

- Heavy reliance on advanced computing auditing tools to facilitate audit procedures.

- $\quad$ Strong emphasis placed on examining audit evidence derived from a wide variety of sources, i.e. both internal and external, for the audit client.

- $\quad$ Use of risk-based auditing. Risk-based auditing is an audit approach in which an auditor will focus on those areas most likely to contain errors.

Consequently, there is an increasing need for formally-educated entry-level auditing professionals who are equipped with the relevant knowledge on computer auditing tools. Existing employees in auditing firms may find themselves reluctant to adopt the technology skills but prefer to recruit readymade technology savvy young auditors (Richardson and Louwers, 2010). Accordingly, institutions of higher learning, and stakeholder organizations that provide education in these fields, are faced with a number of questions regarding the nature, extent, and format of a worthwhile curriculum. Generally, most institutions of higher learning wish to provide current, up-to-date and real world software applications to their students, but face a number of common difficulties like hardware, software, training and administration issues. Thus, the objective of our study is to explore ways to bridge the expectation gap of the industry and existing auditing syllabus. We aim to answer the questions concerning the opportunities and methodologies available to educators in integrating CAATs in the audit classroom. This is done 
through analysis of the extant literature. Next, the students' responses towards the methodology used in our classroom is sought by administering a survey as well as tabulation of the results of the classroom test. It is expected that the results of this study would be able to facilitate other institutions of higher learning, globally, and in Malaysia, particularly, to integrate the usage of GAS into the syllabus of auditing courses. Pragmatically, students who have learnt to use such tools before entering the auditing profession will have a distinct advantage in the marketplace.

This paper is organized as follows: in the next section the prior literature on CAATTs adoption by professionals and educators is explored. Section 3 then presents the analysis of teaching methodology and the approach adopted. Section 4 details the findings and discussion. Finally, Section 5 offers some conclusions and implications as well as discussing limitations to this work.

The key contributions of this paper are:

- Development of methodology for incorporating technology into classroom teaching of auditing.

- Provision of local data on students' awareness and motivation to learn GAS.

- $\quad$ Provision of students' feedback on GAS learning experience, which can motivate educators to adopt the approach.

\section{Literature Review}

The existence of transaction data in a non-electronic form is becoming increasingly scarce as companies make effective use of point-of-sale systems as well as business to consumer (B2C) electronic commerce. In addition, the use of electronic data interchange (EDI) continues to increase with respect to business to business (B2B) and business to government (B2G) transactions. These trends strongly suggest the need for increased use of technology in the audit process (Braun and Davis, 2003). Therefore, in today's age of automated information, auditors' utilization of CAATTs has become a necessity and not a luxury.

Auditors have used many types of CAATT since the 1960s, which Grand (2001) summarizes as electronic working papers, fraud detection, information retrieval and analysis, network security, continuous monitoring, audit reporting, database of audit history, computer based training, electronic commerce and Internet security. The most frequently-used of all the CAATTs is GAS, which allows for data extraction and analysis. This audit technology is perceived to enhance audit efficiency and effectiveness (Braun and Davis., 2003; Bierstaker et al., 2003; Fischer et al., 1993). The key reasons for the widespread use of GAS include its relative simplicity, in that it requires little specialized information system knowledge, and its adaptability to a variety of environments and users (Braun and Davis, 2003). 


\subsection{CAATTs adoption in auditing profession}

CAATTs usage in auditing has evolved since the 1960s (Elliot, 1987) until today. GAS, in particular, is widely used by internal auditors, external auditors and information system auditors. Towards the end of the 1990s and early 2000, more literature on CAATTs was published (see Pyzik, 1997; Paukowits, 2000; Pogrob, 1999; Gonen, E, 2000; Debreceny ${ }^{\mathrm{a}}$ et al., 2003; Bierstaker et al., 2001; Grand, 2001; Kalaba, 2002; Braun and Davis, 2003; Auditnet, 2003, Richardson and Louwers, 2010, Ahmi and Kent, 2013). This literature demonstrates that the awareness of, and interest in CAATTs have increased recently. There are also surveys and research conducted by professional accounting associations on many issues relating to CAATTs usage. For example, in 1995, the Institute of Internal Auditors Incorporated (IIA), based in the USA, conducted their first survey of audit software usage by internal auditors. The first survey analysed the experiences of 12 auditors from different organizations throughout the USA in using audit software. Subsequently, in 1996, the survey was repeated on a larger scale. Questionnaires were sent to 1,000 respondents. Almost half of the respondents were from the USA and Canada while the rest were from 16 other nations. The results of the survey confirmed the strong impact of technology on the internal audit profession (Prawitt et al., 2003). The survey of audit software became an annual event until 2006 when IIA released the 12th Annual Survey results, which reported the improved usage by internal auditors around the world. Thereafter, CAATTs have been deemed to be an indispensable tool that all auditors are expected to utilize during the audit.

\subsection{CAATTs in the classroom}

Globally, accounting and auditing educators realized that the challenges brought by economic and technological development required a re-evaluation of the auditing syllabus taught in universities (Vasarhelyi, Teeter and Krahel, 2010). The extant literature pointed out the failures of accounting undergraduate programmes to meet the industry requirements. For example, a working paper by Shannon and McCartney (1992) discussed the failure of course curricula to prepare graduates to become effective auditors. Fresh graduates appeared to not have adequate electronic data processing (EDP) knowledge, were unable to recognize the benefit of CAATTs as well as incompetent in the use of CAATTs (Shannon and McCartney, 1992). Two important points that necessitate a review and/or modifications of the curriculum include the course content and usage of technology (Albrecht and Sack, 2000). According to research done in 2000 (Albrecht and Sack, 2000) the areas of concern are as follows:

- The curricula are too narrow and often outdated or irrelevant. They are driven by the interests of the faculty and not by the demands of the market. 
- Students are not exposed in the right ways to highly-relevant concepts, such as globalization, technology, and ethics.

- The teaching of accounting is as if information is still costly. Information is now inexpensive and the part of our curriculum that is devoted to information gathering and recording is a waste of time.

- Information processing, which has been an important part of the educational model, can now be managed quickly by anyone using the right software.

- The students are not adequately exposed to the impact of technology on business, or to the ways in which technology can be leveraged to make business decisions.

In the USA, many universities have made substantial changes to their curriculum content and teaching methodology (AAA, 2005). One of the changes is by incorporating CAATTs in the auditing classroom. Several studies have documented the methodology and findings on the issues of integrating CAATTs in the teaching of auditing (For example, McCombs and Sharifi, 2004; Arel et al., 2003; and Gelinas et al., 2001).

In Malaysia, local universities are gradually responding to the global change in auditing education. Realizing the latest development and huge expectations in the auditing profession, particularly the demand for CAATTs knowledge and skills, we embarked on the project to incorporate the knowledge and skills on CAATTs in the auditing courses. Our aim is to produce graduates who are theoretically sound and practically competent. In addition, no such study as those conducted in the USA has been carried out in Malaysia. In addition, neither of these previous studies tailored the ACL assignments to a particular textbook that is being used by the students, the absence of which may cause the students difficulties in relating the hands-on technical ACL skills to the theories in the textbook. It is hoped that this study will contribute to fill the gap.

\subsection{Teaching methodology}

Integrating GAS in the classroom requires careful planning of the teaching methodology. It may also require changes in the teaching approach (Boyce, 1999). It is indeed challenging in a scenario where students need to learn the theoretical approach of auditing, and, simultaneously, they are expected to apply that knowledge in practical auditing work. The classroom itself is far from being able to demonstrate the complexity of auditing issues in the real world. In the USA, the auditing pedagogy has changed to include team projects, student presentations and case studies (Armitage, 2007; AAA, 2003). A few other approaches are outlined by Vasarhelyi, Teeter and Krahel (2010), which include team stimulation, remote projects, contextual learning and supplemental instructions. Gelinas et al. (2001) suggest a case study approach for efficiently integrating GAS into the classroom. 
In the case study produced by Gelinas et al. (2001) - Norwood Office Supplies Inc - three assignments on ACL (a type of GAS) were given together with case descriptions. The objective of each assignment is as per table 1 .

Table 1: Assignment objectives in Norwood Office Supplies Inc (Source: Gelinas et al., 2001)

\begin{tabular}{|c|l|}
\hline $\begin{array}{c}\text { Assignment } \\
\text { Number }\end{array}$ & Objectives \\
\hline 1 & Walkthrough of basic features and to familiarize with the software \\
\hline 2 & $\begin{array}{l}\text { To identify business objectives, related risks and control, as well } \\
\text { as audit procedures }\end{array}$ \\
\hline 3 & $\begin{array}{l}\text { Apply the test to relevant audit objectives, and document the } \\
\text { conclusion }\end{array}$ \\
\hline
\end{tabular}

On the other hand, McCombs and Sharifi (2004) utilize the educational version of audit software from the two most common GAS vendors, namely, ACL and IDEA (Prawitt et al., 2003). They argued that the straightforward method facilitates the integration because the educational version is freely-licensed and students can download data from the installation CDs. Moreover, students can also check the printout of their work from the answers given in the training materials. This method releases the burden on the educators' time, and the effort of preparing the education materials.

Nevertheless, the choice of methodology depends on the facilities available to the educators and the educational institution. Facilitating conditions are important criteria for successful GAS adoption, in particular (Mahzan and Lymer, 2009), and IT adoption, in general (Venkatesh et al., 2003).

\section{Teaching Simulation and Data Collection Methods}

We identified three important steps that need to be conducted in order to answer the two questions that we identified on page three. The steps are, first, to identify the resources available; second, to choose the right teaching simulation approach and implementation process; and, lastly, collect data on the students' evaluation. We explain each of these steps as follows:

\subsection{Resources}

Availability of resources is one of the important elements for ensuring the success of this study; principle aspects are software availability, knowledge and experience of teaching faculty, and adequacy of computer hardware. With regards to software, we deliberated on the choice of software based on ease of access, functionality and vendor support. We considered ACL and IDEA and finally chose ACL due to 
the availability of vendor support. ACL offers an educational support programme known as ACL Futures.

While in the process of applying for the ACL Futures Program, we decided to use an education version of the software that is included in the international version of the text book by Messier et al. (2007). The software is supported by online teaching resources available for instructors. This textbook is adopted as one of the recommended texts for advance auditing courses.

One of the facilitating factors in this study is the availability of two teaching faculty staff, who have experience with GAS. One of them has almost ten years internal auditing experience in which she frequently used GAS. The other teaching faculty member did her PhD thesis on the adoption of CAATTs by internal auditors. Both of them play the role of champion for GAS integration in auditing courses. In addition, a training course is conducted for other teaching faculty staff to introduce the benefit of the software and its fundamental functions.

\subsection{Teaching simulation and implementation approach}

This study employed a similar approach to that of McCombs and Sharifi (2004) by adopting materials provided by textbook. Students are encouraged to purchase the recommend text by Messier et al. (2007), which includes a free ACL CD ROM installation disk. A similar program is installed in computer labs for teaching purposes. However, the assignment materials are modified to follow the step-by-step approach used in Norwood Office Supplies Inc (Gelinas et al., 2005). The assignment materials, however, are not taken from a single textbook but from various textbooks (Hall and Singleton, 2005; Rittenberg et al., 2007), and resource sharing of an audit portal called auditnet.org. The overall teaching plan for ACL is summarized in Table 2.

Table 2: Summary of ACL Teaching Plan

\begin{tabular}{|l|l|l|}
\hline Teaching Method & Hours allocated & Instructional Material \\
\hline $\begin{array}{l}\text { Mass lecture on CAATTs } \\
\text { overview and functions }\end{array}$ & 2 & $\begin{array}{l}\text { PowerPoint Presentation } \\
\text { Lecture Slides provided on } \\
\text { e-learning web portal. }\end{array}$ \\
\hline $\begin{array}{l}\text { Lab demonstration on } \\
\text { ACL }\end{array}$ & $\begin{array}{l}8 \text { (comprised 4 different } \\
\text { sessions of 2 hours } \\
\text { duration each) }\end{array}$ & $\begin{array}{l}\text { PowerPoint presentation slides } \\
\text { and practice questions. }\end{array}$ \\
\hline Assignments & Self-study & $\begin{array}{l}\text { Assignments in e-learning web } \\
\text { portal. }\end{array}$ \\
\hline
\end{tabular}




\subsection{Data collection on students' response.}

In order to assess the effectiveness of the teaching simulation approach to students learning of auditing, we evaluated the students' response through the direct and indirect methods. Based on the literature relating to the assessment of learning, the direct method refers to test, quiz or examination while the indirect assessment of learning can be done through surveys (Pringle and Michel, 2007). Consequently we decided to conduct two assessments, which are test and survey.

At the end of all the ACL sessions (Mass lecture, lab demonstration and assignments), students are given a simple test that carries $10 \%$ towards their final marks for the advanced auditing course. The test is conducted in a computer lab, however, due to the limited space available, the tests have to be conducted in two separate sessions. The second session follows immediately after the first one to ensure confidentiality. The students are given 90 minutes to finish the questions. Answers are exported to the Excel program and sent through email to the lecturer. The lecturer monitors the online and real-time receipt of the answers.

The final process of the study is to obtain students' feedback through a survey administered after the test. The survey instrument comprises demographic and cognitive questions, which are adapted from Mahzan and Lymer (2009). The cognitive questions are designed based on a 7-point Likert scale (Field, 2005) in which 1 represents strong agreement and 7 represents strong disagreement

\section{Findings and Analysis}

In this section we present our findings on students responses to the teaching methodology adopted through the two types of learning assessment described in the previous section. Assessment and analysis of the outcome is done in two ways. Firstly, by looking at the results of ACL test given to students, and, secondly, through the survey instrument that is adapted from Mahzan and Lymer (2009). The results of the tests are appended in table 3.

Table 3: Results of Class Test

\begin{tabular}{|l|c|c|}
\hline Marks range (out of full marks of 10) & N & Percentage \\
\hline $8-10$ & 27 & $27.84 \%$ \\
\hline $6-8$ & 34 & $35.05 \%$ \\
\hline $4-5$ & 36 & $37.11 \%$ \\
\hline Below 4 & 0 & \\
\hline Total & 97 & $100 \%$ \\
\hline
\end{tabular}


From table 3, it shows that more than half of the students obtained marks of 60 per cent and above while none of them obtained marks below 40 per cent. On the basis of 10 contact hours, as explained in table 2, it can be concluded that the students have demonstrated a good understanding of the ACL basic functions, and, at the same time, they are able to relate to the audit objectives and analysis. Next, we present the survey results.

Table 4: Students' demographic profiles

\begin{tabular}{|c|c|c|c|}
\hline Demographic & & Frequency & Per cent \\
\hline \multirow{4}{*}{ Year of Study } & \multirow{2}{*}{ Third } & 74 & 76.3 \\
\hline & & 23 & 23.7 \\
\hline & Final & 97 & 100.0 \\
\hline & & & \\
\hline \multirow{4}{*}{ Gender } & \multirow{4}{*}{$\begin{array}{l}\text { Male } \\
\text { Female } \\
\text { Total }\end{array}$} & 20 & 20.6 \\
\hline & & 77 & 79.4 \\
\hline & & 97 & 100.0 \\
\hline & & & \\
\hline \multirow{3}{*}{ Age } & 21 to 24 & 85 & 87.6 \\
\hline & 25 to 30 & 12 & 12.4 \\
\hline & Total & 97 & 100.0 \\
\hline \multirow{4}{*}{$\begin{array}{l}\text { Audit Software } \\
\text { Used }\end{array}$} & $\begin{array}{l}\text { a. Electronic Working paper (Audit } \\
\text { Express) }\end{array}$ & 1 & 1.0 \\
\hline & $\begin{array}{l}\text { b. Generalized Data Analysis Software } \\
\text { (ACL) }\end{array}$ & 67 & 69.1 \\
\hline & $a$ and $b$ & 29 & 28.9 \\
\hline & Total & 97 & 100.0 \\
\hline
\end{tabular}

The results of the survey were processed using SPSS statistical package, and the preliminary findings of the descriptive statistics are presented in tables 4 and 5 .

From table 4, it is noted that most students who responded possessed experience in using either an electronic working paper or generalized data analysis software or both. The knowledge and skill concerning electronic working paper, even though not formally taught in the classroom, is provided to the students through a series of workshops conducted by our MOU Partner, AXP Solutions Sdn Bhd. Students have the option to undertake a three-day workshop at a subsidized cost. 
Embracing Technology in Auditing Courses: Opportunities, Methodology and Challenges

Table 5: Descriptive Statistics on survey questions

\begin{tabular}{|c|c|c|c|c|c|}
\hline Questions & $\mathrm{N}$ & Minimum & Maximum & Mean & $\begin{array}{c}\text { Std. } \\
\text { Deviation }\end{array}$ \\
\hline accomplish audit tasks more quickly & 97 & 1.00 & 7.00 & 1.8969 & 1.03566 \\
\hline difficulty explaining to others & 96 & 1.00 & 7.00 & 4.1667 & 1.63943 \\
\hline able to use trial basis & 97 & 1.00 & 6.00 & 2.7320 & 1.28708 \\
\hline compatible with work & 97 & 1.00 & 6.00 & 2.4639 & 1.01100 \\
\hline learning to operate is easy & 97 & 1.00 & 7.00 & 3.1031 & 1.34230 \\
\hline give higher status in the organization & 97 & 1.00 & 7.00 & 2.6082 & 1.15069 \\
\hline quality of work improves. & 97 & 1.00 & 5.00 & 2.1134 & .91146 \\
\hline $\begin{array}{l}\text { communicate to others the pros and } \\
\text { cons }\end{array}$ & 97 & 1.00 & 6.00 & 2.9278 & 1.11100 \\
\hline $\begin{array}{l}\text { permitted to use on a trial basis long } \\
\text { enough }\end{array}$ & 97 & 1.00 & 7.00 & 3.1237 & 1.38638 \\
\hline fit my work requirement & 96 & 1.00 & 6.00 & 2.4583 & 1.00438 \\
\hline seen many people with CAATTS & 97 & 1.00 & 7.00 & 4.2990 & 1.59534 \\
\hline $\begin{array}{l}\text { that it is easy to get CAATTS to do the } \\
\text { audit tasks }\end{array}$ & 97 & 1.00 & 6.00 & 2.7010 & 1.20039 \\
\hline my effectiveness on the job & 97 & 1.00 & 5.00 & 2.1031 & .89541 \\
\hline make my job easier & 97 & 1.00 & 5.00 & 2.2165 & .97068 \\
\hline more prestige in the organization & 97 & 1.00 & 6.00 & 2.5876 & 1.16147 \\
\hline consider adopting CAATTS & 97 & 1.00 & 5.00 & 2.3402 & .95619 \\
\hline $\begin{array}{l}\text { complex information technology, } \\
\text { adopting CAATTS. }\end{array}$ & 97 & 1.00 & 5.00 & 2.2577 & .99245 \\
\hline $\begin{array}{l}\text { consider adopting CAATTS even if my } \\
\text { boss does not require }\end{array}$ & 97 & 1.00 & 7.00 & 3.3505 & 1.25034 \\
\hline not compulsory to use CAATTS & 97 & 1.00 & 7.00 & 2.9691 & 1.12225 \\
\hline $\begin{array}{l}\text { use CAATTS in my job within the next } \\
\text { six months }\end{array}$ & 97 & 1.00 & 7.00 & 3.1546 & 1.12120 \\
\hline I plan to experiment with more usage & 97 & 1.00 & 7.00 & 2.8660 & 1.08617 \\
\hline extremely positive & 83 & 1.00 & 5.00 & 2.5783 & 1.08336 \\
\hline extremely good & 25 & 1.00 & 4.00 & 2.4800 & .82260 \\
\hline extremely beneficial & 24 & 1.00 & 5.00 & 2.3750 & 1.13492 \\
\hline
\end{tabular}


From table 5, based on the Likert scale where 1 represents strong agreement and 7 represents strong disagreement, it demonstrates that students are positive towards the benefits and usage of CAATTs (response to question within a mean below 3). The only exception is question 11 , where the mean is 4.29. This implies that the respondents have not previously seen many people using CAATTs. In addition, question 2, which negatively probes that it is difficult to explain CAATTs to others, shows a mean above 4 . This reveals that students do not agree with such a statement.

\section{Conclusion, Limitations and Future Work}

Based on our findings, the preliminary attempt to integrate GAS in the auditing classroom shows a positive response. By adopting the textbook materials and modifying them based on the approach used by Gelinas et al. (2001), we are able to impart GAS basic skills and integrate them with auditing knowledge. The process, however, is not without challenges. Based on the experience gathered from this project, we identified a few challenges, which include the availability of adequate computer facilities and the difficulty in generating new cases and dummy data to be used for GAS interrogation. Despite the challenges, the success of this study helps to spearhead future plans to develop cases and experiment with different types of test to assess students' learning achievement. We also identify the twofold implications of this paper; to educators and practitioners who provide training on GAS. This paper highlights to both parties the positive responses (opportunity), methodology and challenges that can be adopted for integrating GAS in the teaching of auditing courses. The limitation of this study, however, is due to the limited scope of the simulation respondents, which is only one batch of students. In future research, it is recommended that data on students' responses be collected through a longitudinal study.

\section{References}

Albrecth, W. S; Sack R.J, (2000). Accounting Education: Charting the Course Through a Perilous Future, Accounting Education Series, American Accounting Association, Volume 16.

Ahmi, A., Kent, S., (2013). The utilization of generalized audit software (GAS) by external auditors. Managerial Auditing journal, 28(2),

Auditnet, (2003). Principles of Computer Assisted Audit Techniques - an AuditNet ${ }^{\circledR}$ Monograph Series Guide in cooperation with INTOSAI (online) http://www.auditnet.org/caatt.htm (Accessed January 2004).

Armitage, J., (2008), Changes in Importance of topics in auditing education: 2000-2005, Managerial Auditing Journal, 2000-2005, 23(9); pp 935-959. 
American Accounting Association (AAA) Auditing Section (2003). Challenges to Audit Education for the $21^{\text {st }}$ Century : A survey of Curricula, Course Content and Delivery Methods. Issues in Accounting Education, 18(3) ; 241- 263

Bierstaker, J.L., Burnaby, P. and Thibodeau, J. (2001). The Impact of Information Technology on The Audit Process: An assessment of the State Of The Art and Implications for the Future. Managerial Auditing Journal, 16 (3): 159-164.

Braun, R.,L., and Davis, H.,E.,(2003). Computer Assisted Audit Tools and Techniques: Analysis and Perspectives. Managerial Auditing Journal, 18(9): 725-731.

Boyce, G. (1999). Computer-assisted teaching and learning in accounting: pedagogy or product?' Journal of Accounting Education, Vol. 17, pp. 191-220.

Boritz, J. E. \& Datardina, D. (2007). CAATs in the Classroom', Working Paper. University of Waterloo.

CICA, (1994). The Application of CAATTS using Microcomputers Research Report. The Canadian Institute of Chartered Accountants, Toronto, Ontario

Debreceny,d, R. S., Lee, S. -L., Neo, W., and Toh, J. S. (2006). Employing Generalized Audit Software in the Financial Services Sector: Challenges and Opportunities. Managerial Auditing Journal, 20 (6): 605-618.

Elliott, R. and P. Jacobson (1987), Audit Technology: A Heritage and a Promise. Journal of Accountancy, (May): 198-219.

Field, (2005). Discovering Statistics using SPSS, California, Sage Publication

Fischer, Michael, J., McAllister and John, P, (1993). Enhancing efficiency with new audit technology, The CPA Journal. New York, 63(11): 58.

Gelinas, Ulric, Elliot and Thibodeau (2001). Norwood Office Supplies Inc., A teaching case to integrate CAATs into the auditing course. Issues in Accounting Education, p 603-636.

Grand, C.L., (2001) Use of Computer-Assisted Audit Tools and Technique (CAATTs) Part 1, IT Audit, Vol. 4, October 1, The Institute of Internal Auditor http://www.theiia.org/itaudit/index.cfm?fuseaction=forum\&fid=320

Gonen, E. (2000). Evaluation of Automated Software Testing Tools, IT Audit, Vol. 3, December 1, The Institute of Internal Auditor, USA(online). http:// www.theiia.org/itaudit/index.cfm? fuseaction=forum \&fid $=67$

Hall, J. and Singleton, T., (2005). Information Technology Auditing and Assurance, $2^{\text {nd }}$ edition, New York, South Western.

Hudson, M.E., (1998). CAATTs and Compliance. Internal Auditor, 55(2): 25-27. Kalaba, L.A., (2002). The Benefit of CAATTS, IT Audit, Vol. 4, The Institute of Internal Auditor Inc, Florida (online) http://www.theiia.org/itaudit/index. cfm?fuseaction=forum\&fid=428. Accessed March 2003.

Mahzan, N, Lymer, A. (2009). Examining Adoption of Computer Assisted Audit Tools and Techniques (CAATTs): Cases of UK internal Auditors, Proceedings of 12th International Business Information Management Association (IBIMA) Conference, in Kuala Lumpur, Malaysia, June 2009. 
Matherly, M.,Watson, MW., Ivancevich, S.(2009). Implementing Generalized Audit Software in the Classroom, AIS Educator Journal,4(1) pp 27-54.

McCombs, G. B. \& Sharifi, M. (2004). Utilization of Generalized audit software in an information systems auditing course. Information Systems Control Journal, Vol. 6, pp. 1-3.

Messier, W.F. Jr. \& Boh, M. (2007). Auditing \& Assurance Services in Malaysia. McGraw-Hill. (Ed.)

Paukowits, F. (2000). Bridging CAATTS and Risk. Internal Auditor, Vol. 57, Issue 2, p27

Paukowits, F., (1998). Mainstreaming CAATTS. Internal Auditor, Vol. 55, Issue $1, \mathrm{p} 19$.

Pogrob, K.R., Isenberg, G. (1999). Accountants corner: Auditing in a paperless society. The Secured Lender, New York, 55(7): 126.

Prawitt, Douglas, F., Romney and Marshall, B. (1996). Super Software. Internal Auditor, 53 (4): 16

Pringle, C., Michel, M., (2007). Assessment practices in AACSB-accredited business schools. Journal of Education for Business,82(4),p202-211

Pyzik, K.P. (1997). Building a better toolbox, The Internal Auditor, The Institute of Internal Auditors Inc., Vol. 54(2).

Richardson, RC., Louwers, TJ.(2010). Using computerized Audit Software to Learn Statistical Sampling: An Instructional Resource. Issues in Accounting Education, 25 (3)p 553-567

Rittenberg, E. and Bradley J (2005). Auditing: Concepts for a Changing Environment, $5^{\text {th }}$ Edition, SWLearning, USA.

Singleton, T. (2006). Generalized Audit Software: Effective and Efficient Tool for Today's IT Audits. Information Systems Control Journal, Volume 2.

Vasarhelyi, MA., Teeter, RA, Krahel, JP. (2010). Audit Education and the RealTime Economy, Issues in Accounting Education, 25 (3) p 405-423. Venkatesh, V., Morris, M., Davis, G. and Davis, F.D. (2003). User acceptance of information technology: toward a unified view. MIS Quarterly, 27(3): 425-478. 